\title{
Physiological responses of three temperate coralline algae from contrasting habitats to near-future ocean acidification
}

\author{
Q13 Fanny Noisette ${ }^{\mathrm{a}, \mathrm{b}, *}$, Hronn Egilsdottir ${ }^{\mathrm{c}, \mathrm{d}}$, Dominique Davoult ${ }^{\mathrm{a}, \mathrm{b}}$, Sophie Martin ${ }^{\mathrm{a}, \mathrm{b}}$ \\ a CNRS, UMR 7144, Station Biologique de Roscoff, Place Georges Teissier, 29688 Roscoff Cedex, France \\ b UPMC Univ. Paris 6, UMR 7144, Station Biologique de Roscoff, Place Georges Teissier, 29688 Roscoff Cedex, France \\ c Marine Research Institute, Skulagata 4, 121 Reykjavik, Iceland \\ d University of Iceland, Faculty of Earth Science, Askja, Sturlugata 7, 101 Reykjavik, Iceland
}

\section{A R T I C L E I N F O}

\section{Article history:}

Received 28 March 2013

Received in revised form 5 July 2013

Accepted 8 July 2013

Available online $\mathrm{xxxx}$

\section{Keywords:}

Calcification

Corallinaceae

Mg-calcite

$p \mathrm{CO}_{2}$

Photosynthesis

Rhodolith

\begin{abstract}
A B S T R A C T
Coralline algae are major calcifiers of significant ecological importance in marine habitats but are among the 25 most sensitive calcifying organisms to ocean acidification. The elevated $\mathrm{pCO}_{2}$ effects were examined in three 26 coralline algal species living in contrasting habitats from intertidal to subtidal zones on the north-western 27 coast of Brittany, France: (i) Corallina elongata, a branched alga found in tidal rock pools, (ii) Lithophyllum 28 incrustans, a crustose coralline alga from the low intertidal zone, and (iii) Lithothamnion corallioides (maerl), a 29 free-living form inhabiting the subtidal zone. Metabolic rates were assessed on specimens grown for one 30 month at varying $p \mathrm{CO}_{2}: 380$ (current $p \mathrm{CO}_{2}$ ), 550, 750 and $1000 \mu$ atm (elevated $p \mathrm{CO}_{2}$ ). There was no $p \mathrm{CO}_{2}$ effect 31 on gross production in C. elongata and L. incrustans but L. incrustans respiration strongly increased with elevated 32 $\mathrm{pCO}_{2}$. L. corallioides gross production slightly increased at $1000 \mu \mathrm{tm}$, while respiration remained unaffected. 33 Calcification rates decreased with $\mathrm{pCO}_{2}$ in L. incrustans (both in the light and dark) and L. corallioides (only in 34 the light), while $C$. elongata calcification was unaffected. This was consistent with the lower skeletal $\mathrm{mMg} / \mathrm{Ca} 35$ ratio of $C$. elongata (0.17) relative to the two other species (0.20). L. incrustans had a higher occurrence of 36 bleaching that increased with increasing $\mathrm{pCO}_{2} \cdot \mathrm{pCO}_{2}$ could indirectly impact this coralline species physiology 37 making them more sensitive to other stresses such as diseases or pathogens. These results underlined that the 38 physiological response of coralline algae to near-future ocean acidification is species-specific and that species 39 experiencing naturally strong $\mathrm{pH}$ variations were not necessarily more resistant to elevated $\mathrm{pCO}_{2}$ than species 40 from more stable environment.

(C) 2013 Elsevier B.V. All rights reserved. 42

\section{Introduction}

Coralline algae (Corallinaceae, Rhodophyceae) are the most dominant group of calcareous algae. They are abundant and widespread around the world from tropical to polar oceans and throughout the photic zone (Nelson, 2009). In benthic coastal areas, they are major framework builders and carbonate producers (Cabioch et al., 1992; Nelson, 2009). Corallinaceae developed different morphologies: geniculate (articulated) algae have erected, branched thalli with uncalcified joints between calcified segments; non-geniculate (non-articulated) algae are crusts attached to the substratum or occur as free-living forms called rhodolithes (Cabioch et al., 1992). In shallow waters where they develop, they have important biological and ecological roles (Foster, 2001) and are considered ecosystem engineers (Nelson, 2009). They participate in reef accretion acting as cement (Adey, 1998; Jokiel et al., 2008) or can build large habitats as coralligenous or rhodolith beds. They favor larval

\footnotetext{
* Corresponding author at: CNRS, UMR 7144, Station Biologique de Roscoff, Place Georges Teissier, 29688 Roscoff Cedex, France. Tel.: + 33298292333.

E-mail addresses: fanny.noisette@sb-roscoff.fr (F. Noisette), hronne@gmail.com (H. Egilsdottir), davoult@roscoff.fr (D. Davoult), sophie.martin@sb-roscoff.fr (S. Martin).
}

recruitment and settlement of marine invertebrates (Adey, 1998), acting 62 as nurseries for some commercial molluscs and fishes (Kamenos et al., 63 2004a,b). They increase benthic biodiversity, providing hard substratum 64 to settle and microhabitats for shelter (Foster, 2001; Grall et al., 2006; 65 Pena and Barbara, 2010).

In temperate waters, coralline algae can be found at various depths, 67 from the intertidal to the subtidal zone. In the intertidal zone, they fre- 68 quently inhabit rock pools, forming dense mats at the edges or covering 69 the bottom of the pools (Cabioch et al., 1992). Because rock pools are 70 disconnected from the open sea at low tide, large $\mathrm{pH}$ variations are 71 common in this habitat (Morris \&Taylor, 1983). Diurnal variation 72 often exceeds one $\mathrm{pH}$ units, as a result of photosynthesis and respiration 73 (Björk et al., 2004; Morris and Taylor, 1983; Truchot and Duhameljouve, 74 1980). In the low intertidal zone where channels are formed in shallow 75 waters, understory coralline algae develop on rocks and pebbles under 76 the dense macroalgal canopy. Under the canopy, pH fluctuates 77 according to depth, photosynthetic production, wave exposure, flow 78 or irradiance and is likely to present strong diurnal variations of more 79 than one unit (Middelboe and Hansen, 2007). In the subtidal zone, 80 rhodoliths form large beds. These rhodolith beds grow in stable 81 environments with reduced flow (Foster, 2001) and relatively low pH 82 
variation (Teichert et al., 2012). In all these habitats, coralline algae are important contributors to the global carbon budget and carbonate production through their high community primary production and respiration and their high calcium carbonate production (Amado-Filho et al., 2012; Bensoussan and Gattuso, 2007; Martin et al., 2005, 2007).

Photosynthesis, respiration and calcification are linked metabolic processes that can influence each other (Borowitzka, 1981; De Beer and Larkum, 2001; Gao et al., 1993; Martin et al., 2013). Via $\mathrm{CO}_{2}$ uptakes and outputs, photosynthesis and respiration processes cause increase and decrease of $\mathrm{pH}$ respectively, in the intracellular medium and in the diffusive boundary layer (Raven and Hurd, 2012). These variations will increase the rate of calcification in the light and decrease it in the dark. Very few studies have investigated these processes all together, especially in coralline algae. Coralline species precipitate calcium carbonate $\left(\mathrm{CaCO}_{3}\right)$ containing magnesium (i.e. high magnesian calcite, Mg-calcite) to form their thallus. This biogenic $\mathrm{CaCO}_{3}$ is more soluble than aragonite at mole percentage ( $\mathrm{mol} \%) \mathrm{MgCO}_{3}$ higher than $12 \%$ (Andersson et al., 2008). In the Corallinales order, the mean mol\% $\mathrm{MgCO}_{3}$ in calcite is $13 \%$ but varies depending on the taxa considered from $14 \%$ in Corallina genus or $25 \%$ in the Lithothamnion genus (Smith et al., 2012). Due to the solubility of their skeleton, coralline algae might be among the most sensitive organisms to $\mathrm{CO}_{2}$-driven ocean acidification (Basso, 2012; Kroeker et al., 2010).

The ocean acidification phenomenon is generated by the constant increase in atmospheric $\mathrm{CO}_{2}$ partial pressure $\left(p \mathrm{CO}_{2}\right)$ since the $1800 \mathrm{~s}$ (Sabine et al., 2004). Surface ocean pH is predicted to decrease by $0.3-0.4$ units by 2100 and by 0.7 units by the year 2300 (Caldeira and Wickett, 2003). Simultaneously, the concentration of bicarbonate ions $\left(\mathrm{HCO}_{3}^{-}\right)$is predicted to increase and carbonate ions $\left(\mathrm{CO}_{3}^{2-}\right)$ concentration to drop by $30 \%$ by the end of the century (Orr et al., 2005). The $\mathrm{CaCO}_{3}$ saturation state $(\Omega)$, which is dependent on the $\mathrm{CO}_{3}^{2-}$ concentration and influences $\mathrm{CaCO}_{3}$ precipitation, is consequently expected to decrease (Feely et al., 2004). Such changes in seawater chemistry may have direct impacts on metabolic processes, particularly ones using dissolved inorganic carbon (DIC) as a substrate, and thus affect both calcifying and photosynthetic marine organisms such as coralline algae.

Responses to high $p \mathrm{CO}_{2}$ of coralline algae belonging to different morphological or taxonomical groups are variable and species-specific (see Martin et al., 2013 for a review). Most of them are negatively affected with detrimental effects on recruitment (Kuffner et al., 2008), growth (Ragazzola et al., 2012), abundance (Martin et al., 2008), photosynthetic production (Anthony et al., 2008) and calcification (Gao and Zheng, 2010). Bleaching associated to mortality (Anthony et al., 2008; Diaz-Pulido et al., 2012) has also been found to increase in response to high $\mathrm{pCO}_{2}$. Conversely, some authors reported a positive effect on photosynthetic (Borowitzka, 1981) and calcification processes (Martin et al., 2013) or parabolic responses of calcification to increased $p \mathrm{CO}_{2}$ (Johnson and Carpenter, 2012; Ries et al., 2009). The variability of the algal responses also depends on the abiotic parameters applied during the experiments. For example, calcification of Hydrolithon onkodes measured under $336 \mu \mathrm{mol}$ photons $\mathrm{m}^{-2} \mathrm{~s}^{-1}$ presented a parabolic response with the highest calcification rate under the intermediate levels of $530 \mu \mathrm{atm}$ (Johnson and Carpenter, 2012) whereas a constant calcification decrease was measured under $1200 \mu \mathrm{mol}$ photons $\mathrm{m}^{-2} \mathrm{~s}^{-1}$ on the same species (Diaz-Pulido et al., 2012). Hofmann et al. demonstrated with the same technique (PAM fluorometry) that photosynthesis in Corallina officinalis can decrease (Hofmann et al., 2012a) or remain stable (Hofmann et al., 2012b) with an increase in $\mathrm{pCO}_{2}$. As responses of living organisms are so varying, applying the same abiotic parameters is required to compare speciesspecific responses.

In the present study, the metabolic processes of photosynthesis, respiration and calcification were investigated simultaneously in different algal species from contrasting habitats in response to elevated $\mathrm{pCO}_{2}$. Assuming that organisms inhabiting highly variable environments are likely to be more robust to ocean acidification (Harley et al., 2012; 149 Raven et al., 2012) and able to tolerate high $\mathrm{pH} / \mathrm{pCO}_{2}$ fluctuations, $150 \mathbf{Q} 2$ we hypothesized that coralline algae living in fluctuating habitats 151 (intertidal rock pools and channels) will be less affected by elevated 152 $p \mathrm{CO}_{2}$ than algae from more stable subtidal environments. We inves- 153 tigated the physiological responses of three different algal species: 154 Corallina elongata, an erected coralline alga from rock pools; 155 Lithophyllum incrustans, a pink thick crustose coralline alga (CCA) 156 which covers the pebbles in tidal channels and Lithothmanion 157 corallioides, also called "maerl", a key species forming rhodolith 158 beds in the subtidal zone.

\subsection{Biological material}

Three coralline algal species living in contrasting environments from 162 the intertidal to the subtidal zone on the north-western coast of Brittany 163 were selected for this experiment.

(1) C. elongata Ellis and Solander, 1786, is a geniculate alga erected 165 from a basal crust, composed of numerous articulated calcareous 166 branches. It is a perennial species from the intertidal zone, 167 abundant on exposed shores, which forms a continuous mat at 168 rock pool edges along Atlantic and Mediterranean coasts 169 (Cabioch et al., 1992). Specimens of C. elongata were sampled 170 on October 11th, 2010 in a shaded rock pool on the low intertidal 171 shore of "Les Amiets", Cléder $\left(48^{\circ} 41.45^{\prime} \mathrm{N}, 4^{\circ} 7.26^{\prime} \mathrm{W}\right)$. Algal 172 fronds free of epiphytic organisms were selected for the experi- 173 ment and carefully separated from their substrate to obtain 174 their encrusting base. In October 2012, under sunny conditions, 175 temperature fluctuated by about $1{ }^{\circ} \mathrm{C}$, from $16.4{ }^{\circ} \mathrm{C}$ just after dis- 176 connection from the sea (pool emersion) to $17.5^{\circ} \mathrm{C}$ just before 177 immersion at rising tide. Changes in temperature between the 178 night and day can reach $4{ }^{\circ} \mathrm{C}$ in such low intertidal shaded rock 179 pools (see Egilsdottir et al., 2013). The pH on the total scale 180 $\left(\mathrm{pH}_{\mathrm{T}}\right)$ in such a rock pool can vary locally according to the 181 depth of the pool and the presence of other macroalgae between 182 8.61 and 7.82, corresponding to 70 and $1000 \mu$ atm, respectively 183 (see Egilsdottir et al., 2013). The photosynthetic active radiations 184 (PAR) measured using a flat quantum sensor (LiCor ${ }^{\circledR}$, LI-192 SA) 185 at midday under sunny conditions at the surface of the pool was 186 around $30 \mu \mathrm{mol}$ photons $\mathrm{m}^{-2} \mathrm{~s}^{-1}$. This low light was due to a 187 large rock overhanging the pool and shading the pool area 188 along the day.

(2) L. incrustans Philippi, 1837, is a non-geniculate coralline alga 191 forming thick pink/grey crusts covering the substrate. The thallus 192 surface is variable in terms of color, thickness and shape, the oldest 193 ones forming thick, rippled and peeled off margins (Steneck, 194 1986). This species is usually immersed (Littler, 1972) and can 195 be found in rock pools and in the sub-canopy in the low intertidal. 196 Small pebbles entirely covered by $L$. incrustans were collected on 197 October 13th, 2010 in the middle of the Green Island Channel, 198 front of the Station Biologique de Roscoff ( $\left.48^{\circ} 43.73^{\prime} \mathrm{N}, 3^{\circ} 59.22^{\prime} \mathrm{W}\right) .199$ Selected thalli were completely pink, (without white patches) 200 characteristic of healthy crusts. In this channel, depth can vary be- 201 tween a few centimetres to meters between high and low tides 202 and spring and neap tides. Abiotic parameters were measured in 203 October 2012 at low water mean spring tide (similar environmen- 204 tal conditions as during the algal collection). Temperature varied 205 from $17.5{ }^{\circ} \mathrm{C}$ at midday on a sunny day to $16.2{ }^{\circ} \mathrm{C}$ during the 206 night. Under the dense Sargassum muticum canopy, $\mathrm{pH}_{\mathrm{T}}$ at low 207 tide fluctuated between $7.83\left(\mathrm{pCO}_{2} \approx 700 \mu \mathrm{atm}\right)$ during the 208 night and $8.74\left(p \mathrm{CO}_{2} \approx 50 \mu \mathrm{atm}\right)$ during the day, under sunny 209 
conditions. Incident irradiance measured at the surface at midday during low tide using a flat quantum sensor (LiCor®, LI-192 SA) was around $800 \mu \mathrm{mol}$ photons $\mathrm{m}^{-2} \mathrm{~s}^{-1}$. Using an under-canopy extinction coefficient calculated in laboratory (coefficient $\approx 16.2$; Noël, unpublished data), incident irradiance was estimated less than $50 \mu \mathrm{mol}$ photons $\mathrm{m}^{-2} \mathrm{~s}^{-1}$ in the understory.

(3) L. corralioides crouan \& crouan, 1867 is a non-geniculate free-living form of coralline algae. This species forms extensive beds, called rhodolith or "maerl" beds, by accumulating live and dead thalli (Foster, 2001). L. corralioides thalli were collected by SCUBA diving on October 13th, 2010, in a maerl bed of the Bay of Morlaix at the Guérhéon site $\left(48^{\circ} 42.66^{\prime} \mathrm{N}, 3^{\circ} 57.06^{\prime} \mathrm{W}\right)$, at $7 \mathrm{~m}$ depth below Chart Datum. Individuals between 1.5 and $3 \mathrm{~cm}$ in diameter were selected for the experiment. Abiotic parameters at the Guérhéon site were characterized in October 2012. Temperature was stable around $16.3{ }^{\circ} \mathrm{C} . \mathrm{pH}_{\mathrm{T}}$ varied between 8.12 and 8.18 units before and after high tide (290-340 $\mu \mathrm{atm})$. Irradiance measured with a PAR spherical sensor (biospherical QSP200PD) at $9 \mathrm{~m}$ depth reached $27 \mu \mathrm{mol}$ photons $\mathrm{m}^{-2} \mathrm{~s}^{-1}$ in the midday under cloudy (but bright) conditions which corresponds to $15 \mu \mathrm{mol}$ photons $\mathrm{m}^{-2} \mathrm{~s}^{-1}$ with a flat sensor (factor conversion: 0.57 see Ouisse et al., 2011).

\subsection{Experimental conditions and set-up}

After collection, all samples were transferred directly to a cool box maintaining in situ temperature and carried to the laboratory at the Station Biologique de Roscoff. Specimens were selected, gently cleaned to remove most epiphytes and biofilm forming organisms and were maintained in natural unfiltered seawater until the beginning of the experiment.

Sets of 4-6 C. elongata fronds, 5-6 L. incrustans pebbles and 4-5 L. corralioides thalli were labeled with small plastic numbers attached with nylon wire. Two sets of each algal species were randomly distributed to each of the twelve $10-\mathrm{L}$ aquaria composing the experimental set up. In addition, unlabelled thalli were kept in each aquarium for chlorophyll analyses. The thalli were softly brushed to take off epiphytes and biofilm before proceeding to the different measurements. Dry weight (DW) of each alga was determined at the end of the experiment after oven drying fresh samples at $60{ }^{\circ} \mathrm{C}$ for $48 \mathrm{~h}$. Then, thalli were burned for $4 \mathrm{~h}$ at $450{ }^{\circ} \mathrm{C}$ to obtain ash-free dry weight (AFDW).

At the beginning of the experiment, (October 19th to 26th, 2010), $\mathrm{pH}$ was progressively decreased by $0.05 \mathrm{pH}$ units per day by gradually increasing the $\mathrm{pCO}_{2}$ to avoid algae any drastic stress. Then, the organisms were acclimated for one month (October 26th to November 23th, 2010) to the different $p \mathrm{CO}_{2} / \mathrm{pH}_{\mathrm{T}}$ conditions reached, selected according to the recommendations of Riebesell et al. (2010): $380 \mu \mathrm{tm}$ $\left(\mathrm{pH}_{\mathrm{T}}=8.07\right)$ was selected as the current $p \mathrm{CO}_{2}$, and $550 \mu \mathrm{atm}$ $\left(\mathrm{pH}_{\mathrm{T}}=7.94\right), 750 \mu \mathrm{atm}\left(\mathrm{pH}_{\mathrm{T}}=7.82\right)$ and $1000 \mu \mathrm{atm}\left(\mathrm{pH}_{\mathrm{T}}=7.77\right)$ as three elevated $p \mathrm{CO}_{2}$ corresponding to different scenarios predicted by the Intergovernmental Panel on Climate Change (IPCC) for the end of the century (Solomon et al., 2007). The $\mathrm{pCO}_{2}$ were adjusted by bubbling $\mathrm{CO}_{2}$-free air to increase $\mathrm{pH}$ (current atmospheric $p \mathrm{CO}_{2}$ ) or 261 pure $\mathrm{CO}_{2}$ to decrease $\mathrm{pH}$ (elevated $p \mathrm{CO}_{2}$ ) in four $100 \mathrm{~L}$ header tanks. 262 These tanks were continuously supplied with unfiltered seawater 263 pumped in from the $1800 \mathrm{~m}^{3}$ water reservoir of the Station Biologique 264 de Roscoff that fills up at high tide. Seawater was delivered from each 265 tank to a triplicate of aquaria at a rate of $100 \mathrm{ml} \mathrm{min}^{-1}$ (i.e. a renewal 266 rate of $60 \% \mathrm{~h}^{-1}$ ). The 12 aquaria were placed in temperature controlled 267 baths regulated by 100 and $150 \mathrm{~W}$ submersible heaters at $16{ }^{\circ} \mathrm{C} \pm 268$ $0.02{ }^{\circ} \mathrm{C}$ (October mean in situ temperature). $p \mathrm{CO}_{2}$ and temperature 269 were monitored and controlled by an off line feedback system (IKS 270 Aquastar, Karlsbad, Germany) that regulated the addition of gas in 271 the tanks and the on/off heater switch in the temperature controlled 272 bath. The $\mathrm{pH}$ values of the $\mathrm{pH}$-stat system were adjusted from daily 273 measurements of $\mathrm{pH}$ on the total scale $\left(\mathrm{pH}_{\mathrm{T}}\right)$ in the aquaria using a $\mathrm{pH} 274$ meter (HQ40D, Hach Lange, Ltd portable LDO ${ }^{\mathrm{TM}}$, Loveland, Colorado, 275 USA) calibrated using Tris/ $/ \mathrm{HCl}$ and 2-aminopyridine/ $\mathrm{HCl}$ buffer 276 (Dickson et al., 2007). Light was provided by $39 \mathrm{~W}$ fluorescent tubes 277 (JBL Solar Ultra Marin Day, JBL Aquaria, Nelson, New Zealand). Irradi- 278 ance was fixed at a mean value of $30 \mu \mathrm{mol}$ photons $\mathrm{m}^{-2} \mathrm{~s}^{-1}$, represen- 279 tative of mean daily in situ irradiance in the three habitats, by adjusting 280 the distance of the fluorescent tubes above the aquaria and using a 281 quantum sensor (LiCor ${ }^{\circledR}$, LI-192 SA). The photoperiod was adjusted to 282 9:15 (light:dark, h) corresponding to the mean photoperiod in Autumn. 283

\subsection{Seawater parameters}

Seawater parameters were monitored throughout the experiment. 285 $\mathrm{pH}_{\mathrm{T}}$ and temperature were recorded daily in each of the twelve aquaria 286 with a pH-meter (HQ40D, Hach Lange, Ltd portable LDO ${ }^{\mathrm{TM}}$, Loveland, 287 Colorado, USA). Total alkalinity $\left(\mathrm{A}_{\mathrm{T}}\right)$ was measured in the four $\mathrm{pCO}_{2} 288$ treatments by $\mathrm{HCl} 0.01 \mathrm{~N}$ potentiometric titration on an automatic 289 titrator (Titroline alpha, Schott SI Analytics, Mainz, Germany) at the 290 beginning of the acclimation period (28th October 2010) and during 291 the acquisition of metabolic rates (23th-26th November 2010). Salinity 292 was checked in each aquarium at the beginning, twice during the 293 experiment and at the end of the experiment with a conductimeter 294 (LF 330/SET, WTW, Weilheim, Germany). The carbonate chemistry 295 of the seawater, i.e. dissolved inorganic carbon (DIC), exact $\mathrm{CO}_{2} 296$ partial pressure $\left(p \mathrm{CO}_{2}\right)$ and saturation state of aragonite $\left(\Omega_{\mathrm{Ar}}\right.$, be- 297 cause solubility of high Mg-calcite is closer to aragonite than calcite) 298 were calculated for each aquarium using $\mathrm{CO}_{2}$ SYS software (Lewis 299 and Wallace, 1998) with constants of Mehrbach et al. (1973) 300 (refitted by Dickson and Millero, 1987). Mean values of the parame- 301 ters in each $p \mathrm{CO}_{2}$ condition ( 3 aquaria per condition) are presented 302 in Table 1.

\section{4. $\mathrm{mMg} / \mathrm{Ca}$, chlorophyll $a$ and bleaching analyses}

The $\mathrm{mol} \% \mathrm{Mg} / \mathrm{Ca}(\mathrm{mMg} / \mathrm{Ca})$ ratio was analyzed in three samples per 305 algal species, only in the control condition ( $380 \mu \mathrm{atm})$ at the end of the 306 experiment. The algae did not grow enough in one month to produce 307 sufficient quantity of carbonate to perform comparisons between 308 $p \mathrm{CO}_{2}$ treatments. Samples were cleaned with distilled water, dried by 309 paper towel tapping, bagged and sent to the Institute of Earth Sciences, 310

\section{Table 1}

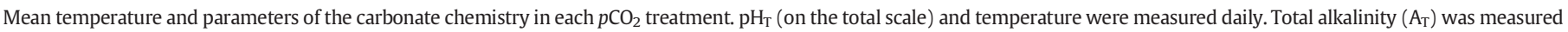

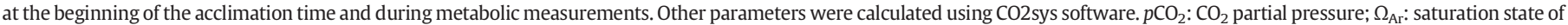
seawater with respect to aragonite.

\begin{tabular}{|c|c|c|c|c|c|}
\hline \multirow[t]{2}{*}{$p \mathrm{CO}_{2}$ treatments } & $\begin{array}{l}\text { Temperature } \\
\left({ }^{\circ} \mathrm{C}\right)\end{array}$ & $\mathrm{pH}_{\mathrm{T}}$ & $\begin{array}{l}\mathrm{A}_{\mathrm{T}} \\
(\mu \mathrm{Eq})\end{array}$ & $\begin{array}{l}p \mathrm{CO}_{2} \\
\text { ( } \mu \text { atm) }\end{array}$ & $\Omega_{\mathrm{Ar}}$ \\
\hline & $\mathrm{n}=32$ & $\mathrm{n}=32$ & $\mathrm{n}=35$ & $\mathrm{n}=32$ & $\mathrm{n}=32$ \\
\hline $380 \mu$ atm & $16.0 \pm 0.1$ & $8.01 \pm 0.01$ & $2401.92 \pm 3.78$ & $450 \pm 7$ & $2.41 \pm 0.03$ \\
\hline $550 \mu \mathrm{atm}$ & $15.9 \pm 0.1$ & $7.88 \pm 0.01$ & $2402.07 \pm 3.08$ & $637 \pm 23$ & $1.88 \pm 0.05$ \\
\hline $750 \mu \mathrm{atm}$ & $15.9 \pm 0.1$ & $7.80 \pm 0.01$ & $2414.49 \pm 4.18$ & $790 \pm 22$ & $1.58 \pm 0.03$ \\
\hline $1000 \mu \mathrm{atm}$ & $15.9 \pm 0.1$ & $7.70 \pm 0.01$ & $2418.53 \pm 5.16$ & $1002 \pm 24$ & $1.29 \pm 0.03$ \\
\hline
\end{tabular}


University of Iceland. Small samples $(<0.01 \mathrm{~g})$ of the skeletal material of each alga were placed in $20 \mathrm{ml}$ polyethylene vials which had been cleaned by soaking for 3 days in $5 \% \mathrm{HNO}_{3}$ and then washed with distilled water and dried. To dissolve calcium carbonate, $1 \mathrm{ml}$ of $65 \%$ $\mathrm{HNO}_{3}$ suprapure acid (Merck, Germany) was added to the samples and left to dissolve for $14 \mathrm{~h}$, after which $4 \mathrm{ml}$ of deionised purified water (Milli-Q purification system, Millipore, USA) was added to the sample. The $\mathrm{mol} \% \mathrm{Mg} / \mathrm{Ca}(\mathrm{mMg} / \mathrm{Ca})$ ratios were analyzed at the University of Iceland Institute of Earth Sciences, with an Inductively Coupled PlasmaAtomic Emission Spectrometer (ICP-AES Spectro Ciros ${ }^{\text {TM }}$, Germany). The ICP-analysis was calibrated with mixtures of NIST-traceable single element solutions (Spex Industries Inc. NJ, USA).

Chlorophyll $a$ (Chl $a$ ) content was measured in the three algal species exposed to each $p \mathrm{CO}_{2}$ treatment at the end of the experiment. Samples from the additive algal pool of each aquarium were removed and immediately frozen at $-20{ }^{\circ} \mathrm{C}$ pending analyses. Branches of C. elongata fronds $(\approx 50 \mathrm{mg})$ and pieces of $L$. corallioides thalli $(\approx 1 \mathrm{~g})$ were removed from the samples just taken out of the freezer. Pink surfaces of $L$. incrustans, around $1 \mathrm{~cm}^{2}$ per thallus, were scratched with a scalpel to pick out the living cell layer. All the samples were weighed and then ground in $10 \mathrm{ml} 90 \%$ acetone with a cold mortar pestle, on an ice bath, under dark conditions. The extract was poured into $15 \mathrm{ml}$ centrifuge tubes and placed in the dark at $4{ }^{\circ} \mathrm{C}$ overnight. Samples were then centrifuged for $20 \mathrm{~min}$ at $4000 \mathrm{rpm}$. Total Chl $a$ concentration in the supernatant was determined according to the method of Ritchie (2008), using a spectrophotometer (Helios Gamma, Thermo Electron Corporation, England). Two successive extractions were necessary for a complete $\mathrm{Chl} a$ extraction.

Bleaching was evaluated at the end of the experiment. White patches of thalli, characteristic of bleaching only occurred in L. incrustans. The surfaces of incubated alga sets were photographed at the end of the experiment. Images were analyzed with ImageJ software (Rasband, version 1.37) to calculate the percentage of the bleached thallus surfaces.

\subsection{Metabolic rates measurements}

Each set of labeled thalli was incubated between the 23th and the 26th November, once in the light and once in the dark, in $80 \mathrm{~mL}$ (L. incrustans and L. corallioides) or $190 \mathrm{~mL}$ (C. elongata) acrylic respirometry chambers (Engineering \& Design Plastics Ltd, Cambridge, UK) filled with the aquarium seawater. Water homogeneity was insured by hand shacking and temperature was kept constant. Light incubations were carried out under culture irradiance ( $30 \mu \mathrm{mol}$ photon $\mathrm{m}^{-2} \mathrm{~s}^{-1}$ ) and dark incubations by covering the aquaria with black plastic bags with fluorescent tubes switched off. Incubations lasted around $3 \mathrm{~h}$ in order to avoid oxygen saturation greater than $120 \%$ during light incubation and maintain oxygen saturation above $80 \%$ at the end of the dark incubation. In parallel, control incubations without algae were carried out to correct fluxes from any biological activity in seawater.

Net production (light incubation) and respiration rates (dark incubation) were calculated, by measuring oxygen molar concentration at the beginning and the end of the incubation period with a non-invasive optical fiber system (FIBOX 3, PreSens, Regensburg, Germany). The reactive oxygen spots in the chambers were calibrated just before the beginning of the measurements with $0 \%$ and $100 \%$ oxygen buffers. Net production (NP), respiration (R) and gross production (GP) rates (in $\mu \mathrm{mol} \mathrm{O}_{2} \mathrm{~g}^{-1} \mathrm{AFDW} \mathrm{h}{ }^{-1}$ ) were corrected from controls and calculated as:

$\mathrm{NP}=\left(\Delta \mathrm{O}_{2} \times \mathrm{V}\right) /(\Delta \mathrm{t} \times \mathrm{AFDW})$

$\mathrm{R}=\left(\Delta \mathrm{O}_{2} \times \mathrm{V}\right) /(\Delta \mathrm{t} \times \mathrm{AFDW})$

$\mathrm{GP}=\mathrm{NP}-\mathrm{R}$

where $\Delta \mathrm{O}_{2}$ is the difference between initial and final $\mathrm{O}_{2}$ concentrations in $\mu \mathrm{mol} \mathrm{O} \mathrm{O}_{2} \mathrm{~L}^{-1} ; \mathrm{V}$ is the volume of the chamber in liters; $\Delta \mathrm{t}$ is the incubation time in hour and AFDW is the ash-free dry weight of 370 the algae in grams.

Calcification fluxes were estimated by using the alkalinity anomaly 372 technique (Smith \& Key, 1975) based on a decrease of total alkalinity 373 Q4 $\left(\mathrm{A}_{\mathrm{T}}\right)$ by 2 equivalents for each mole of $\mathrm{CaCO}_{3}$ precipitated (Wolf- 374 Gladrow et al., 2007). Seawater was sampled directly in the aquaria at 375 the beginning of the incubation and in the incubation chamber at the 376 end. Samples were filtered through $0.7 \mu \mathrm{m}$ Whatman GF/F filters into 377 $100 \mathrm{~mL}$ glass bottles and immediately poisoned with mercuric chloride 378 $\left(0.02 \% \mathrm{vol} / \mathrm{vol}\right.$; Dickson et al., 2007). $\mathrm{A}_{\mathrm{T}}$ value (in $\mu \mathrm{Eq} \mathrm{\textrm {L } ^ { - 1 }}$ ) were 379 determined by $\mathrm{HCl} 0.01 \mathrm{~N}$ potentiometric titration on an automatic titra- 380 tor (Titroline alpha, Schott SI Analytics, Mainz, Germany) and by using 381 the Gran method of non-linear least-squares fit applied to $\mathrm{pH}$ values 382 from 3.5 to 3.0 (Dickson et al., 2007). Light and dark calcification rates 383 ( $\mathrm{g}$ light and g dark, in $\mu \mathrm{mol} \mathrm{CaCO}_{3} \mathrm{~g}^{-1} \mathrm{DW} \mathrm{h}^{-1}$ ) were corrected from 384 controls and calculated as:

$\mathrm{g}=-\left(\Delta \mathrm{A}_{\mathrm{T}} \times \mathrm{V}\right) /(2 \times \Delta \mathrm{t} \times \mathrm{DW})$

where $\Delta A_{T}$ is the difference between initial and final total alkalinity con- 388 centrations in $\mu \mathrm{Eq} \mathrm{L}{ }^{-1} ; \mathrm{V}$ is the volume of the chamber in liters; $\Delta \mathrm{t}$ is the 388 incubation time in hour and DW is the dry weight of the algae in grams. 389

\subsection{Statistics}

All statistical analyses were performed using the free software R 391 2.15.0 version (@The R Foundation for Statistical Computing). Before 392 applying each test, normality of the data and homoscedasticity were 393 checked by Shapiro's test and Levene's test respectively. Differences in 394 $\mathrm{mMg} / \mathrm{Ca}$ ratio between the three algal species at $380 \mu \mathrm{atm}$ and percent- 395 age of bleaching among the different $p \mathrm{CO}_{2}$ treatments in L. incrustans 396 were explored by one-way analysis of variance (ANOVA) following by 397 post hoc Student-Newman-Keuls (SNK) test. Because of heterogeneous 398 variances, chlorophyll contents among the algal species and among the 399 $p \mathrm{CO}_{2}$ conditions were compared by two different Kruskal-Wallis tests 400 followed by post hoc Dunn's tests. The effect of $\mathrm{pCO}_{2}$ on metabolic 401 rates was investigated with the GAD package independently for each 402 alga. All the metabolic rates were explored through nested two-ways 403 ANOVA considering " $p \mathrm{CO}_{2}$ " as a fixed factor with 4 levels (390, 550, 404 750 and $1000 \mu \mathrm{atm}$ ) and "aquarium" as a 3 level random factor nested 405 in the " $\mathrm{pCO}_{2}$ " one to deal with spatial pseudo-replication. In cases 406 of significant differences between treatments, a post hoc Student- 407 Newman-Keuls test was applied to explore them. All results are 408 presented as mean \pm standard error.

\section{Results}

410

\subsection{Seawater parameters}

411

Salinity remained stable at $35.2 \pm 0.1$ during the experiment. Mean 412 values of the seawater parameters i.e. temperature, $\mathrm{pH}_{\mathrm{T}}$, alkalinity, $\mathrm{pCO}_{2} 413$ and calcium carbonate saturation state relative to aragonite, in each 414 $p \mathrm{CO}_{2}$ condition ( 3 aquaria per condition) are presented in Table $1 . \quad 415$

\section{2. $\mathrm{mMg} / \mathrm{Ca}$ ratios, chlorophyll a contents and bleaching}

416

$\mathrm{mMg} / \mathrm{Ca}$ ratios were $0.169 \pm 0.002,0.202 \pm 0.006$ and $0.202 \pm 417$ $0.009 \mathrm{~mol}$ for C. elongata, L. incrustans and L. corallioides respectively. 418 The three algal species showed differences in their skeletal composition 419 (Table 2). L. incrustans and L. corallioides, the two species which have the 420 closest morphotypes, had similar percentages (Table 2) of about 20\% 421 $\mathrm{MgCO}_{3}$. C. elongata precipitated calcite with less magnesium than the 422 other species (Table 2 ) with $17 \% \mathrm{MgCO}_{3}$.

Chlorophyll $a$ contents in the living part of the algae (Table 3) did not 424 differ among $\mathrm{pCO}_{2}$ treatments regardless of algal species (Table 2) while 425 differences appeared between species (Table 2). Chlorophyll a content 426 
t 2.10

$\mathrm{t} 2.11$

$\mathrm{t} 2.12$

t2.13

Table 2

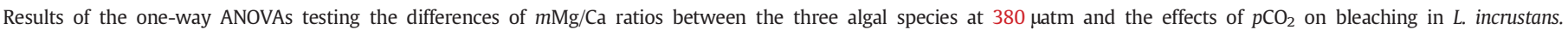
Chlorophyll contents (algal and $p \mathrm{CO}_{2}$ effects) were explored by two Kruskall-Wallis tests.

\begin{tabular}{|c|c|c|c|c|c|c|c|}
\hline & \multirow[b]{2}{*}{ df } & \multicolumn{2}{|c|}{$\mathrm{mMg} / \mathrm{Ca}$ ratio } & \multicolumn{2}{|c|}{ Bleaching } & \multicolumn{2}{|c|}{ Chorophyll contents } \\
\hline & & $\mathrm{F}$ & $\mathrm{p}$ & $\mathrm{F}$ & $\mathrm{p}$ & $\mathrm{H}$ & $\mathrm{p}$ \\
\hline Factor: $p \mathrm{CO}_{2}$ & 3 & & & $\begin{array}{l}7.337 \\
\text { SNK te } \\
380< \\
380< \\
550<\end{array}$ & 0.002 & 0.140 & 0.987 \\
\hline Factor: alga & 2 & $\begin{array}{l}9.241 \\
\text { SNK te } \\
\text { C. elon } \\
\text { C. elon } \\
\text { L. incr }\end{array}$ & $\begin{array}{l}0.015 \\
\text { ins } \\
\text { ides } \\
\text { lioides }\end{array}$ & & & $\begin{array}{l}63.160 \\
\text { Dunn's } \\
\text { C. elong } \\
\text { L. coral }\end{array}$ & $\begin{array}{l}<0.001 \\
l s>\end{array}$ \\
\hline
\end{tabular}

was the highest in C. elongata, intermediate in L. incrustans and the lowest in L. corallioides.

Bleaching occurred only in L. incrustans thalli and was observed in all $p \mathrm{CO}_{2}$ treatments. The percentage of bleached surface at the end of the experiment was significantly affected by $p \mathrm{CO}_{2}$ (Table 2 ) and increased with increasing $p \mathrm{CO}_{2}$ from $1 \%$ of the whole surface of the thalli bleached at $380 \mu$ atm to more than $10 \%$ at $1000 \mu$ atm (Fig. 1 ).

\subsection{Metabolic rates}

In all the metabolic rates, no aquarium effect was detected $(p>0.05$, Table 4).

In C. elongata, the mean rates of net production varied from 12.62

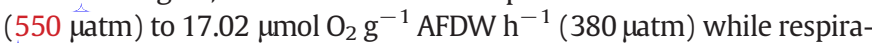
tion and gross production rates reached maxima of -11.87 and $28.89 \mu \mathrm{mol} \mathrm{O}_{2} \mathrm{~g}^{-1} \mathrm{AFDW} \mathrm{h}^{-1}$, respectively (Fig. 2A). Gross production was slightly decreased at $550 \mu \mathrm{atm}$ ( $-24 \%$ relative to $380 \mu \mathrm{atm})$ whereas net production and respiration were not affected by elevated $p \mathrm{CO}_{2}$ (Table 4). Calcification rates in the light and dark were positive except at $1000 \mu \mathrm{atm}$ in the dark (Fig. 2B). No $p \mathrm{CO}_{2}$ effect was detected on calcification both in the light and dark. Mean net calcification ranged from $0.93 \pm 0.71 \mu \mathrm{mol} \mathrm{CaCO}_{3} \mathrm{~g}^{-1} \mathrm{DW} \mathrm{h}{ }^{-1}$ at $550 \mu$ atm to $1.81 \pm$ $0.70 \mu \mathrm{mol} \mathrm{CaCO}_{3} \mathrm{~g}^{-1} \mathrm{DW} \mathrm{h}^{-1}$ at $1000 \mu \mathrm{atm}$ in the light and from $0.78 \pm 0.33 \mu \mathrm{mol} \mathrm{CaCO}_{3} \mathrm{~g}^{-1} \mathrm{DW} \mathrm{h}^{-1}$ at $550 \mu \mathrm{atm}$ to $-0.28 \pm$ $0.41 \mu \mathrm{mol} \mathrm{CaCO}_{3} \mathrm{~g}^{-1} \mathrm{DW} \mathrm{h}{ }^{-1}$ at $1000 \mu \mathrm{atm}$ in the dark. Dissolution (negative net calcification) only occurred at $1000 \mu \mathrm{atm}$ in the dark.

Net production of $L$. incrustans varied from -0.91 to $0.23 \mu \mathrm{mol} \mathrm{O}$ $\mathrm{g}^{-1} \mathrm{AFDW} \mathrm{h}^{-1}$. Gross production rates were not affected by elevated $p \mathrm{CO}_{2}$ but conversely, respiration increased with increasing $p \mathrm{CO}_{2}$ and net production was also affected (Table 4 ). Gross production ranged from 2.26 to $2.58 \mu \mathrm{mol} \mathrm{O}_{2} \mathrm{~g}^{-1}$ AFDW $\mathrm{h}^{-1}$ and respiration rate increased from $-2.04(380 \mu \mathrm{atm})$ to $-3.49 \mathrm{O}_{2} \mathrm{~g}^{-1} \mathrm{AFDW} \mathrm{h}^{-1}$ $(1000 \mu \mathrm{tm})$. Calcification in the light and in the dark (Fig. 2B) decreased with increasing $p \mathrm{CO}_{2}$, as we observed a drop of $185.7 \%$ between 380 and $1000 \mathrm{~atm}$ in the light (from $0.08 \pm 0.03$ to $-0.07 \pm$ $0.03 \mu \mathrm{mol} \mathrm{CaCO}_{3} \mathrm{~g}^{-1} \mathrm{DW} \mathrm{h}^{-1}$ ) and $250 \%$ in the dark (from $-0.06 \pm$ 0.01 to $-0.21 \pm 0.03 \mu \mathrm{mol} \mathrm{CaCO}_{3} \mathrm{~g}^{-1} \mathrm{DW} \mathrm{h}^{-1}$ ). Dissolution, as the net calcification rates were negatives, occurred in the light only under elevated $p \mathrm{CO}_{2}$ (750 and $1000 \mu \mathrm{atm}$ ) and in all the conditions in the dark.

Table 3

Chlorophyll a content in the three coralline algal species in each $p \mathrm{CO}_{2}$.

\begin{tabular}{lllll}
\hline & \multicolumn{4}{l}{ Chlorophyll concentrations (mg chlorophyll g ${ }^{-1}$ AFDW) } \\
\cline { 2 - 5 } & $380 \mu \mathrm{atm}$ & $550 \mu \mathrm{atm}$ & $750 \mu \mathrm{atm}$ & $1000 \mu \mathrm{atm}$ \\
\hline C. elongata & $2.04 \pm 0.10$ & $1.74 \pm 0.13$ & $1.56 \pm 0.24$ & $1.73 \pm 0.06$ \\
L. incrustans & $1.46 \pm 0.03$ & $1.69 \pm 0.18$ & $1.89 \pm 0.10$ & $1.94 \pm 0.24$ \\
L. corallioides & $1.15 \pm 0.04$ & $1.06 \pm 0.03$ & $1.13 \pm 0.07$ & $1.10 \pm 0.05$
\end{tabular}

$L$ corallioides net production rates ranged between 6.39 and 465 $9.23 \mu \mathrm{mol} \mathrm{O}_{2} \mathrm{~g}^{-1} \mathrm{AFDW} \mathrm{h}^{-1}$, at 750 and $380 \mu$ atm respectively. Gross 466 production rates increased from 8.73 to $13.23 \mu \mathrm{mol} \mathrm{O} \mathrm{g}^{-1}$ AFDW h$^{-1} 467$ and respiration rates ranged between $-1.55(750 \mu \mathrm{atm})$ and -4.00468 $\mathrm{O}_{2} \mathrm{~g}^{-1}$ AFDW h ${ }^{-1}(1000 \mu \mathrm{atm})$. Elevated $\mathrm{pCO}_{2}$ affected respiration, 469 net and gross production (Table 4 ) by enhancing primary production 470 at $1000 \mu \mathrm{atm}$ and decreasing respiration at $750 \mu \mathrm{atm}$ (Fig. 2A). With a 471 mean of $0.38 \pm 0.07 \mu \mathrm{mol} \mathrm{CaCO}_{3} \mathrm{~g}^{-1} \mathrm{DW} \mathrm{h}^{-1}$, calcification measured 472 in the light was much higher than calcification in the dark (Fig. 2). 473 $p \mathrm{CO}_{2}$ effects on light calcification were significant $(\mathrm{p}=0.043$, Table 4) 474 even though post hoc comparison tests did not show any significant 475 differences between $\mathrm{pCO}_{2}$ conditions. Dark calcification was not 476 significantly affected by $p \mathrm{CO}_{2}$ (Table 2). However, a general trend $477 \mathbf{Q 5}$ showed a decrease in calcification rates from $0.14 \pm 0.06$ at $380 \mu$ atm 478 to $-0.03 \pm 0.08 \mu \mathrm{mol} \mathrm{CaCO}_{3} \mathrm{~g}^{-1} \mathrm{DW} \mathrm{h}^{-1}$ at $1000 \mu \mathrm{atm}$ in the dark 479 (Fig. 2B). Dissolution occurred in the two most elevated $\mathrm{pCO}_{2}$ condition 480 (750 and $1000 \mu \mathrm{atm}$ ) only in the dark.

\section{Discussion}

Calcifying marine algae show a large variety of responses to ocean 483 acidification (Hurd et al., 2009) and species-specific responses may be 484 developed by algae from the same family living in contrasting habitats 485 to cope with abiotic changes (Harley et al., 2012).

Photosynthesis in the three investigated algal species was not strong- 487 ly impacted by increasing $p \mathrm{CO}_{2}$. Indeed, in C. elongata, gross primary pro- 488 duction was not affected by increasing $\mathrm{pCO}_{2}$ except for an inconsiderable 489 decrease at $550 \mu \mathrm{atm}$. L. incrustans gross production remained constant 490

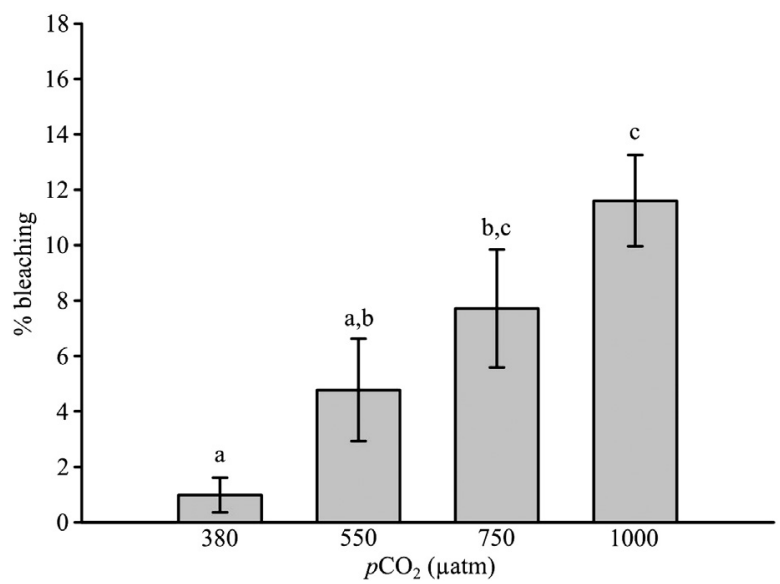

Fig. 1. Percentage of bleaching in Lithophyllum incrustans thalli in each $p \mathrm{CO}_{2}$ treatment. Unshared letters above bars indicate significant differences between treatments $(p<0.05$, SNK post hoc test), $\mathrm{n}=6$. 
Table 4

Results of the one-way nested ANOVA testing the effects of $\mathrm{pCO}_{2}$ on the metabolic rates in the three coralline algal species.

\begin{tabular}{|c|c|c|c|c|c|c|c|c|c|c|c|}
\hline \multirow[b]{3}{*}{$p \mathrm{CO}_{2}$ effect } & \multirow[b]{3}{*}{ df } & \multirow{2}{*}{\multicolumn{2}{|c|}{$\begin{array}{l}\text { Net production } \\
\mu \mathrm{mol} \mathrm{O}_{2} \mathrm{~g}^{-1} \\
\mathrm{AFDW} \mathrm{h}^{-1}\end{array}$}} & \multirow{2}{*}{\multicolumn{2}{|c|}{$\begin{array}{l}\text { Respiration } \\
\mu \mathrm{mol} \mathrm{O} \mathrm{O}_{2} \mathrm{~g}^{-1} \\
\mathrm{AFDW} \mathrm{h}^{-1}\end{array}$}} & \multirow{2}{*}{\multicolumn{2}{|c|}{$\begin{array}{l}\text { Gross production } \\
\mu \mathrm{mol} \mathrm{O} \mathrm{O}_{2} \mathrm{~g}^{-1} \\
\text { AFDW h } \mathrm{h}^{-1}\end{array}$}} & \multirow{2}{*}{\multicolumn{2}{|c|}{$\begin{array}{l}\text { Light calcification } \\
\mu \mathrm{mol} \mathrm{CaCO} \mathrm{g}^{-1} \\
\mathrm{DW} \mathrm{h}^{-1}\end{array}$}} & \multirow{2}{*}{\multicolumn{2}{|c|}{$\begin{array}{l}\text { Dark calcification } \\
\mu \mathrm{mol} \mathrm{CaCO} \mathrm{g}^{-1} \\
\mathrm{DW} \mathrm{h}^{-1}\end{array}$}} \\
\hline & & & & & & & & & & & \\
\hline & & $\mathrm{F}$ & $\mathrm{p}$ & $\mathrm{F}$ & $\mathrm{p}$ & $\mathrm{F}$ & $\mathrm{p}$ & $\mathrm{F}$ & $\mathrm{p}$ & $\mathrm{F}$ & $\mathrm{p}$ \\
\hline C. elongata & 3 & 3.143 & 0.087 & 2.250 & 0.160 & 11.136 & $0.003 * *$ & 0.659 & 0.600 & 1.431 & 0.304 \\
\hline L. incrustans & 3 & 18.608 & $<0.001^{* * *}$ & 5.328 & $0.026^{*}$ & 0.133 & 0.938 & 18.262 & $<0.001 * * *$ & 11.908 & $0.003 * *$ \\
\hline L. corallioides & 3 & 6.612 & $0.015^{*}$ & 7.271 & $0.011^{*}$ & 9.573 & $0.005^{* *}$ & 4.340 & $0.043^{*}$ & 1.211 & 0.366 \\
\hline
\end{tabular}

$* \mathrm{p}<0.05$

$* * \mathrm{p}<0.01$.

$* * * \mathrm{p}<0.001$

at all the $p \mathrm{CO}_{2}$ treatments while $L$. corallioides gross production increased at $1000 \mu \mathrm{atm}$. This general weak $p \mathrm{CO}_{2}$ effect on coralline algal photosynthesis has already been demonstrated by several authors. For example, photosynthetic rates did not vary in response to increasing $p \mathrm{CO}_{2}$ in the articulated coralline C. officinalis (Hofmann et al., 2012b) and in the crustose coralline alga Hydrolithon sp. (Semesi et al., 2009). Such nonresponsiveness has been attributed to carbon-concentrating mechanisms (CCMs) present in many coralline algae (Giordano et al., 2005).

The CCMs transport bicarbonate ions $\left(\mathrm{HCO}_{3}^{-}\right)$through the cell walls by using ion channels or catalyze the transformation of $\mathrm{HCO}_{3}^{-}$in $\mathrm{CO}_{2}$ via a carbonic anhydrase enzyme (Raven et al., 2012). Photosynthetic rates of macroalgae that have CCMs are not carbon-limited under current environmental conditions (Giordano et al., 2005) and a lack of response of photosynthesis is thus expected under near-future $\mathrm{pCO}_{2}$. The presence of CCMs in C. elongata and L. incrustans has never been reported but these two algae are likely to have CCMs due to their gross produc- 506 tion rate not enhanced by elevated $\mathrm{pCO}_{2}$ (Raven and Hurd, 2012) and 507 the presence of CCM in the taxonomically close species, C. officinalis 508 (Hofmann et al., 2013). Non-CCM macroalgae are generally carbon- 509 limited under current seawater concentration and may respond posi- 510 tively to elevated $p \mathrm{CO}_{2}$ (Kubler et al., 1999). Red macroalgae without 511 CCMs are most common in low light environments and subtidal habitats 512 (Hepburn et al., 2011; Hurd et al., 2009; Middelboe and Hansen, 2007). 513 This is most likely the case for $L$. corallioides which may have benefitted 514 from the higher concentration of photosynthetic substrate $\left(\mathrm{CO}_{2}\right)$ at 515 $1000 \mu \mathrm{atm}$, as demonstrated by its slightly elevated primary production. 516

In contrast to photosynthesis, respiration was differentially affected 517 by $\mathrm{pCO}_{2}$ among the three algal species. C. elongata and $L$. corallioides 518 respiration rates remained unchanged regardless of $\mathrm{pCO}_{2}$. This lack of 519 response is consistent with the lack of $\mathrm{pCO}_{2}$ effect shown in two other 520

A

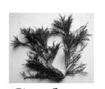

C. elongata

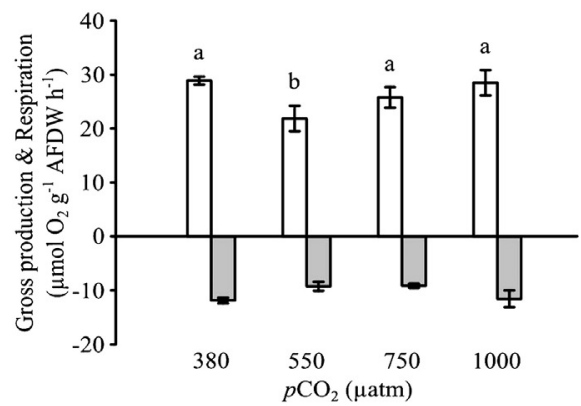

B

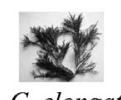

C. elongata

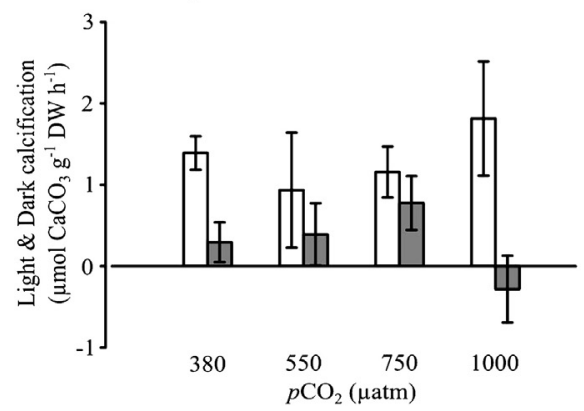

L. incrustans

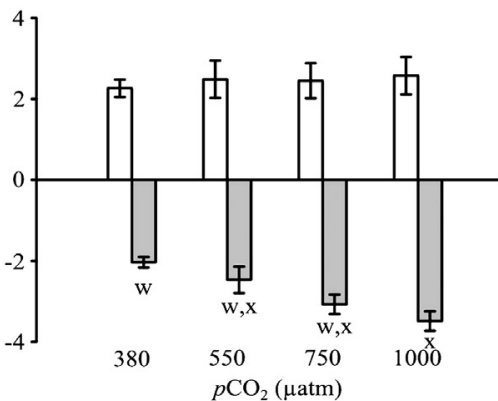

$p \mathrm{CO}_{2}(\mu \mathrm{atm})$

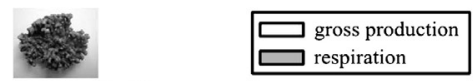

L. corallioides
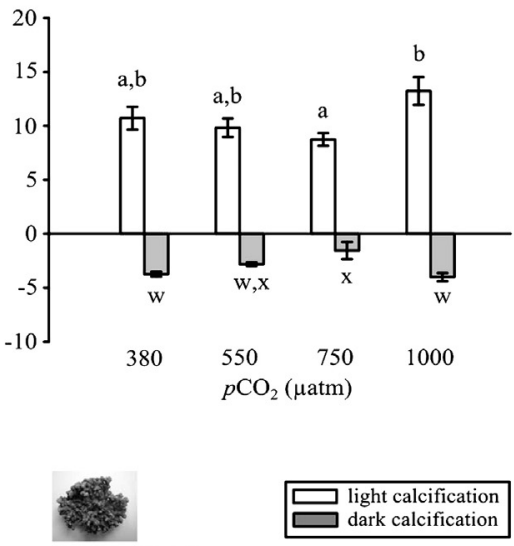

L. corallioides

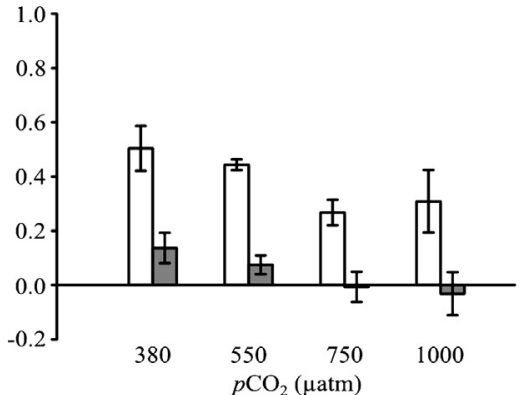

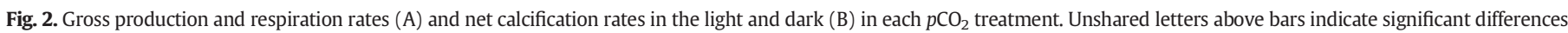
between treatments ( $\mathrm{p}<0.05$, SNK post hoc test), $\mathrm{n}=6$. 
temperate coralline algal species, C. officinalis (Hofmann et al., 2012b) and Lithophyllum cabiochae (Martin et al., 2013) under similar $p \mathrm{CO}_{2}$ ranges. The non-responsiveness of macroalgal respiration under elevated $\mathrm{pCO}_{2}$ was attributed to the absence of changes in photosynthesis and chlorophyll content by Zou et al. (2011). This hypothesis is not supported by our findings since as $L$. corallioides gross production varied significantly without affecting respiration. In contrast, L. incrustans respiration strongly increased under elevated $p \mathrm{CO}_{2}$. This may be related to the severe bleaching occurrence. With bleaching, the proportion of undamaged tissue decreased and necrosis (i.e. dead areas) increased. Non-photosynthetic organisms such as bacteria, fungi, boring organisms may have developed on top and within the dead surfaces (Figueiredo et al., 1997; Tribollet and Payri, 2001), contributing to the increase in respiration rate.

Although bleaching occurred in all the $\mathrm{pCO}_{2}$ treatments, percentage of bleached surfaces increased with increasing $p \mathrm{CO}_{2}$, covering more than $10 \%$ of the total thallus area under $1000 \mu \mathrm{atm}$. Elevated $p \mathrm{CO}_{2}$ is known to increase bleaching in crustose coralline algae (Anthony et al., 2008; Diaz-Pulido et al., 2012; Martin and Gattuso, 2009). However, bleached surfaces were observed in L. incrustans thalli even in the control condition (380 $\mu \mathrm{atm})$ suggesting poor health of this species under experimental conditions. Temperature (Martin and Gattuso, 2009) and desiccation (Martone et al., 2010) are known to be factors inducing crustose coralline algae bleaching. In our experiment, temperature was kept constant at $16{ }^{\circ} \mathrm{C}$ and crustose coralline algae were constantly immersed but other factors such as diseases or pathogens (widely known for tropical crustose coralline algae, Littler and Littler, 1998; Ballantine et al., 2005) may have caused L. incrustans bleaching. This understory species generally inhabits shaded environments, protected by the upper dense canopy from high light intensities (Irving et al., 2004). Although incident irradiance under the canopy may reach 50 umol photon $\mathrm{m}^{-2} \mathrm{~s}^{-1}$ at low tide, the constant light of $30 \mu \mathrm{mol}$ photon $\mathrm{m}^{-2} \mathrm{~s}^{-1}$ applied during the whole experiment may have been too high. In comparison, values reported by Figueiredo et al. (1997) did not exceed 8-24 $\mu \mathrm{mol}$ photons $\mathrm{m}^{-2} \mathrm{~s}^{-1}$ under a Fucus canopy (Isle of Man, UK) at high and low tide respectively. This constant illumination $9 \mathrm{~h}$ per day may have caused damages to cell tissues and led to partial bleaching of the thalli. In elevated $p \mathrm{CO}_{2}$, the potentially negative effects of light may have been amplified at high $\mathrm{CO}_{2}$ concentrations making the algae potentially more perceptive to diseases, increasing the bleaching.

Interestingly, no bleaching was observed in $L$. corallioides although it developed under dim irradiance $\left(\approx 15 \mu \mathrm{mol}\right.$ photons $\left.\mathrm{m}^{-2} \mathrm{~s}^{-1}\right)$. Comparisons between laboratory and in situ recorded metabolic rates suggest that $C$. elongata and $L$. corallioides were in good health and not negatively affected by experimental conditions. At $380 \mu \mathrm{atm}$, $C$. elongata and $L$. corallioides net production rates were higher than those recorded in situ in similar temperature and light conditions (7.7 $\mu \mathrm{mol} \mathrm{O} \mathrm{g}^{-1} \mathrm{~h}^{-1}$; Egilsdottir, pers. com. and $2.4 \mu \mathrm{mol} \mathrm{O} \mathrm{g}^{-1} \mathrm{~d}^{-1}$; Martin et al., 2007, respectively). Daily and hourly net calcification rates in $L$. corallioides (3.1 $\mu \mathrm{mol} \mathrm{CaCO}_{3} \mathrm{~g}^{-1} \mathrm{~d}^{-1}$; Martin et al., 2006) and C. elongata (3.5 $\mu \mathrm{mol} \mathrm{CaCO}_{3} \mathrm{~g}^{-1} \mathrm{~h}^{-1}$, Egilsdottir, pers. com.) respectively, measured in situ were similar to those measured in our study. The consistency between field and laboratory data confirmed that $C$. elongata and L. corallioides were not stressed under the experimental conditions.

Calcification in L. incrustans decreased along the $\mathrm{pCO}_{2}$ gradient, both under light and dark conditions. Daily net calcification rate at $380 \mu \mathrm{atm}$ was low $\left(0.03 \mathrm{mg} \mathrm{CaCO}_{3} \mathrm{~g}^{-1} \mathrm{DW} \mathrm{d}^{-1}\right)$ because of the net dissolution measured under dark conditions, most probably related to the bad health of this alga. Net dissolution was also observed at 750 and $1000 \mu \mathrm{atm}$ in the light and in all the $\mathrm{pCO}_{2}$ conditions in the dark. In contrast with $L$. incrustans, increasing $p \mathrm{CO}_{2}$ did not affect calcification in C. elongata. In $L$. corallioides, calcification rate was significantly affected by elevated $p \mathrm{CO}_{2}$ only in light conditions. In the dark, a general negative trend has been underlined but masked by a high interindividual-response variability. This calcification decrease has already been shown in other rhodolith species (Büdenbender et al., 2011; 587 Ragazzola et al., 2012) and crustose coralline algae (Anthony et al., 588 2008; Jokiel et al., 2008; Semesi et al., 2009). In some species of coralline 589 algae, such as L. cabiochae, dissolution was related to necroses and 590 bleaching (Martin and Gattuso, 2009). In L. incrustans, skeletal dissolu- 591 tion of dead surfaces may have been promoted under elevated $p \mathrm{CO}_{2} 592$ and net calcification subsequently lowered. In the light, this phenome- 593 non was partly buffered by the photosynthesis, which increased the 594 $\mathrm{pH}$ in undamaged tissues and in the boundary layer (Borowitzka, 595 1981; Cornwall et al., 2013; Hurd et al., 2009). By increasing the $\mathrm{pH}, \Omega 596$ was increased and may have favored the calcification process. Con- 597 versely, respiration in the dark released $\mathrm{CO}_{2}$ leading to decrease in $\mathrm{pH} 598$ and $\Omega$. Precipitation of $\mathrm{CaCO}_{3}$ in undamaged tissues may thus be 599 hindered and dissolution exacerbated. $\mathrm{pH}$ variations induced by photo- 600 synthesis and respiration in the surrounding medium of the algae were 601 not likely to affect calcification in C. elongata as this alga may be able to 602 cope with elevated $\mathrm{pCO}_{2}$ by saving energy from down-regulating CCMs 603 (Cornwall et al., 2012; Hurd et al., 2009) or by modifying enzymes 604 contents such as carbonic anhydrase (Hofmann et al., 2012b; 2013) to 605 maintain calcification rates.

Differences between the three algal species could also be partly 607 explained by the high Mg-calcite they precipitate to form their thallus. 608 The carbonate mineralogy is linked to the dissolution phenomenon 609 and can influence calcification rates (Ries, 2011). Mg-calcite is the 610 most soluble form of $\mathrm{CaCO}_{3}$ and the $\mathrm{mol} \% \mathrm{MgCO}_{3}$ in the algal skeleton 611 may increase its solubility (Morse et al., 2006). C. elongata had a lower 612 $\mathrm{mMg} / \mathrm{Ca}$ ratio (0.17) than the other two species (0.20), which can 613 potentially reduce dissolution (Büdenbender et al., 2011). Although 614 information on $\mathrm{mMg} / \mathrm{Ca}$ ratio is not sufficient to define the robustness 615 of a calcareous structure (Ragazzola et al., 2012), a lower magnesium 616 content in $\mathrm{Mg}$-calcite can confer a greater resistance to elevated $p \mathrm{CO}_{2} .617$ Besides, C. elongata has thin, branched thalli that are less calcified than 618 thick crust thalli of $L$. incrustans and L. corallioides. Thallus morphology 619 is known to influence the speed of corrosion (Ragazzola et al., 2012) 620 and the thinnest thallus may be more resistant because of the higher 621 surface to volume ratio that may allow more exchanges leading to a 622 better chemistry regulation around the calcification site (Price et al., 623 2011).

This study has demonstrated that $\mathrm{CO}_{2}$-driven effects varied between 625 algal species from the same family but collected in habitats with varying 626 abiotic conditions. Our original hypothesis that organisms naturally 627 exposed to stressful conditions in their environment will be less 628 sensitive to future $\mathrm{pH} / \mathrm{pCO}_{2}$ variations was partially supported. Indeed, 629 C. elongata was the most resistant to elevated $p \mathrm{CO}_{2}$ and may have 630 developed adaptations to strong daily variations in $\mathrm{pH}$, commonly oc- 631 curring in tidal pools (Truchot and Duhameljouve, 1980). Surprisingly, 632 L. corallioides from a more stable $\mathrm{pH}$ environment showed a better resis- 633 tance than we expected with just a slight decrease in calcification 634 observed under elevated $\mathrm{pCO}_{2}$. This species may benefit from constant 635 optimal temperature and light provided in the mesocosm and might 636 maintain high metabolism even under elevated $\mathrm{pCO}_{2}$. In contrast, 637 L. incrustans, living in shallow-water dominated with macroalgae 638 where $\mathrm{pH}$ fluctuations are high (Middelboe and Hansen, 2007), was 639 the most sensitive to $\mathrm{pCO}_{2}$ increase. However, physiological responses 640 in L. incrustans are likely to be due to bleaching occurrence. Indeed, 641 the bleaching was correlated to an increasing dissolution which implied 642 a tissue deterioration affecting all the metabolic functions (Diaz- 643 Pulido et al., 2012). The increasing bleaching could also be linked to 644 productivity losses as shown on tropical crustose coralline algae 645 (Anthony et al., 2008). The lack of canopy in our experimental set- 646 up may have modify light intensity and quality that L. incrustans is 647 used to, leading to bleaching that not occurs in situ in the understory. 648 If individuals remained healthy and unbleached during the experi- 649 ment, $L$. incrustans could prove to be more resistant and a lack of 650 response to elevated $\mathrm{pCO}_{2}$ may be expected but further investigation 651 is needed. 
High $\mathrm{pCO}_{2}$ sensitivity of coralline algae underlined by numerous authors, (Basso, 2012; Büdenbender et al., 2011; Gao and Zheng, 2010; Hofmann et al., 2012a) is counterbalanced by others studies that showed that calcification could be unaffected (Egilsdottir et al., 2013; Martin and Gattuso, 2009) or even increased (Martin et al., 2013; Ries et al., 2009) by moderate $p \mathrm{CO}_{2}$. These contrasting results and the recent discovery of dolomite, a magnesium-rich stable carbonate less soluble than $\mathrm{Mg}$-calcite, present in some crustose coralline algae led to a reappraisal of the sensitivity of coralline algae to near-future ocean acidification (Nash et al., 2013). However, many studies investigating coralline algae under elevated $p \mathrm{CO}_{2}$ were carried out in mesocosms or laboratory experiments. In the field, $p \mathrm{CO}_{2}$ is not the only stressor, and surely not the main one, impacting algal physiology. Under combined stresses (e.g. light, temperature, $p \mathrm{CO}_{2}$ ), indirect $p \mathrm{CO}_{2}$ effects could enhance the sensitivity of algae and facilitate disease development and bleaching occurrence even if algae are used to large and rapid $\mathrm{pCO}_{2}$ variations in their habitat. As one stressor may limit organism ability to deal with another stressor, bleaching can induce a bias in the physiological responses to increasing $p \mathrm{CO}_{2}$. As for L. incrustans in our study, bleaching induced dissolution that impacted the calcification balance even if calcification process in undamaged part of the thallus may not be affected by elevated $\mathrm{pCO}_{2}$.

Resilience to elevated $p \mathrm{CO}_{2}$ is probable but maybe at a cost (Martin et al., 2013). C. elongata was able to maintain a heavily calcified skeleton under elevated $p \mathrm{CO}_{2}$ during our experiment (one month). In the long term, this ability could impact the general resistance of the organism by decreasing its fitness and could reduce their ability to compete with fleshy algae. In situ experiments along a natural $\mathrm{pH}$ gradient showed that even if coralline algae were able to withstand the effects of ocean acidification, they may suffer reductions in abundance (Hall-Spencer et al., 2008; Kroeker et al., 2013; Martin et al., 2008; Porzio et al., 2011). With the decrease of coralline algae in macroalgal-dominated communities, space could be released for fleshy algae (Kuffner et al., 2008) or turf which are generally favored by elevated $p \mathrm{CO}_{2}$ (Connell and Russell, 2010). As turf and fleshy algae have different ecological roles than coralline algae, these algal community shifts could have considerable ecological and functional consequences for macroalgal communities from the intertidal and subtidal zones.

\section{Uncited reference}

\section{Wood et al., 2008}

\section{Acknowledgments}

The authors thank the Marine Operations and Services Department (SMO) from the Station Biologique de Roscoff for all the diving sampling and the help for system building. In addition we are grateful to the SOMLIT (Service d'Observation en Milieu LITtoral, INSU-CNRS) program for the temperature and nutrient datasets provided to calculate seawater carbon parameters. We also thank the editor and two anonymous reviewers for their helpful and constructive comments on the manuscript. This work was supported by the CALCAO project, which received funding from the Region Bretagne and contributes to the "European Project on Ocean Acidification" (EPOCA) which received funding from the European Community's Seventh Framework Programme (FP7/2007-2013) under grant agreement n_211384. [ST]

\section{References}

Adey, W.H., 1998. Coral reefs: algal structured and mediated ecosystems in shallow, turbulent, alkaline waters. J. Phycol. 34, 393-406.

Amado-Filho, G.M., Moura, R.L., Bastos, A.C., Salgado, L.T., Sumida, P.Y., Guth, A.Z., Francini-Filho, R.B., Pereira-Filho, G.H., Abrantes, D.P., Brasileiro, P.S., Bahia, R.G., Leal, R.N., Kaufman, L., Kleypas, J.A., Farina, M., Thompson, F.L., 2012. Rhodolith beds are major $\mathrm{CaCO}_{3}$ bio-factories in the tropical South West Atlantic. PLoS One 7, 713 e35171.

Andersson, A.J., Mackenzie, F.T., Bates, N.R., 2008. Life on the margin: implications of 715 ocean acidification on Mg-calcite, high latitude and cold-water marine calcifiers. 716 Mar. Ecol. Prog. Ser. 373, 265-273.

Anthony, K.R.N., Kline, D.I., Diaz-Pulido, G., Dove, S., Hoegh-Guldberg, O., 2008. Ocean 718 acidification causes bleaching and productivity loss in coral reef builders. Proc. Natl. 719 Acad. Sci. U. S. A. 105, 17442-17446.

Ballantine, D.L., Weil, E., Ruiz, H., 2005. Coralline white band syndrome, a coralline algal 721 affliction in the tropical Atlantic. Coral Reefs 24, 117.

Basso, D., 2012. Carbonate production by calcareous red algae and global change. 723 Geodiversitas 34, 13-33.

Bensoussan, N., Gattuso, J.P., 2007. Community primary production and calcification in a 725 NW Mediterranean ecosystem dominated by calcareous macroalgae. Mar. Ecol. Prog. 726 Ser. 334, 37-45.

Björk, M., Axelsson, L., Beer, S., 2004. Why is Ulva intestinalis the only macroalga inhabiting 728 isolated rockpools along the Swedish Atlantic coast? Mar. Ecol. Prog. Ser. 284, 109-116. 729

Borowitzka, M.A., 1981. Photosynthesis and calcification in the articulated coralline red 730 algae Amphiroa anceps and Amphiroa foliacea. Mar. Biol. 62, 17-23.

Büdenbender, J., Riebesell, U., Form, A., 2011. Calcification of the Arctic coralline red algae 732 Lithothamnion glaciale in response to elevated $\mathrm{CO}_{2}$. Mar. Ecol. Prog. Ser. 441, 79-87. 733

Cabioch, J., Floch, J.Y., Le Toquin, A., 1992. Guide des algues des mers d'Europe (231 pp.). 734 Caldeira, K., Wickett, M.E., 2003. Anthropogenic carbon and ocean pH. Nature 425, 365.735

Connell, S.D., Russell, B.D., 2010. The direct effects of increasing $\mathrm{CO}_{2}$ and temperature on 736 non-calcifying organisms: increasing the potential for phase shifts in kelp forests. 737 Proc. R. Soc. B Biol. Sci. 277, 1409-1415.

Cornwall, C.E., Hepburn, C.D., Pritchard, D., Currie, K.I., McGraw, C.M., Hunter, K.A., Hurd, 739 C.L., 2012. Carbon-use strategies in macroalgae: differential responses to lowered pH 740 and implications for ocean acidification. J. Phycol. 48, 137-144.

Cornwall, C.E., Hepburn, C.D., Pilditch, C.A., Hurd, C.L., 2013. Concentration boundary 742 layers around complex assemblages of macroalgae: implications for the effects 743 of ocean acidification on understory coralline algae. Limnol. Oceanogr. 58, 744 121-130.

De Beer, D., Larkum, A.W.D., 2001. Photosynthesis and calcification in the calcifying algae 746 Halimeda discoidea studied with microsensors. Plant Cell Environ. 24, 1209-1217. 747

Diaz-Pulido, G., Anthony, K.R.N., Kline, D.I., Dove, S., Hoegh-Guldberg, O., 2012. Interactions 748 between ocean acidification and warming on the mortality and dissolution of coralline 749 algae. J. Phycol. 48, 32-39.

Dickson, A.G., Millero, F.J., 1987. A comparison of the equilibrium constants for the dissocia- 751 tion of carbonic acid in seawater media. Deep-Sea Res. 34, 1733-1743.

Dickson, A., Sabine, C., Christian, J., 2007. Guide to Best Practices for Ocean $\mathrm{CO}_{2}$ Measure- 753 ments (191 pp.).

Egilsdottir, H., Noisette, F., Noel, L.M.L.J., Olafsson, J., Martin, S., 2013. Effects of $\mathrm{pCO}_{2}$ on 755 physiology and skeletal mineralogy in a tidal pool coralline alga Corallina elongata. 756 Mar. Biol. 1-10. http://dx.doi.org/10.1007/s00227-012-2090-7.

Feely, R.A., Sabine, C.L., Lee, K., Berelson, W., Kleypas, J., Fabry, VJ., Millero, F.J., 2004. 758 Impact of anthropogenic $\mathrm{CO}_{2}$ on the $\mathrm{CaCO}_{3}$ system in the oceans. Science 305, 759 362-366.

Figueiredo, M., Norton, T.A., Kain, J.M., 1997. Settlement and survival of epiphytes on two 761 intertidal crustose coralline alga. J. Exp. Mar. Biol. Ecol. 213, 247-260.

Foster, MS., 2001. Rhodoliths: between rocks and soft places. J. I Gao, K.S., Zheng, Y.Q., 2010. Combined effects of ocean acidification and solar UV radiation 764 on photosynthesis, growth, pigmentation and calcification of the coralline alga 765 Corallina sessilis (Rhodophyta). Glob. Change Biol. 16, 2388-2398. 766

Gao, K., Aruga, Y., Asada, K., Kiyohara, M., 1993. Influence of enhanced $\mathrm{CO}_{2}$ on growth and 767 photosynthesis of the red algae Gracilaria sp and Gracilaria chilensis. J. Appl. Phycol. 5, 768 563-571.

Giordano, M., Beardall, J., Raven, J.A., 2005. $\mathrm{CO}_{2}$ concentrating mechanisms in algae: 770 mechanisms, environmental modulation, and evolution. Annu. Rev. Plant Biol. 771 99-131 (Annual Reviews, Palo Alto).

Grall, J., Le Loc'h, F., Guyonnet, B., Riera, P., 2006. Community structure and food web 773 based on stable isotopes $(\delta 15 \mathrm{~N}$ and $\delta 13 \mathrm{C}$ ) analysis of a North Eastern Atlantic 774 maerl bed. J. Exp. Mar. Biol. Ecol. 338, 1-15.

Hall-Spencer, J.M., Rodolfo-Metalpa, R., Martin, S., Ransome, E., Fine, M., Turner, S.M., 776 Rowley, S.J., Tedesco, D., Buia, M.C., 2008. Volcanic carbon dioxide vents show ecosys- 777 tem effects of ocean acidification. Nature 454, 96-99.

Harley, C.D.G., Anderson, K.M., Demes, K.W., Jorve, J.P., Kordas, R.L., Coyle, T.A., Graham, 779 M.H., 2012. Effects of climate change on global seaweed communities. J. Phycol. 48, 780 1064-1078.

Hepburn, C.D., Pritchard, D.W., Cornwall, C.E., McLeod, R.J., Beardall, J., Raven, J.A., Hurd, 782 C.L., 2011. Diversity of carbon use strategies in a kelp forest community: implications 783 for a high $\mathrm{CO}_{2}$ ocean. Glob. Change Biol. 17, 2488-2497. 784

Hofmann, L.C., Straub, S., Bischof, K., 2012a. Competition between calcifying and 785 noncalcifying temperate marine macroalgae under elevated $\mathrm{CO}_{2}$ levels. Mar. 786 Ecol. Prog. Ser. 464, 89-105.

Hofmann, L.C., Yildiz, G., Hanelt, D., Bischof, K., 2012b. Physiological responses of the 788 calcifying rhodophyte, Corallina officinalis (L.), to future $\mathrm{CO}_{2}$ levels. Mar. Biol. 159, 789 783-792.

Hofmann, L.C., Straub, S., Bischof, K., 2013. Elevated CO2 levels affect the activity of nitrate 791 reductase and carbonic anhydrase in the calcifying rhodophyte Corallina officinalis. 792 J. Exp. Bot. 64 (4), 899-908.

Hurd, C.L. Hepburn, C.D. Currie, K.I. Raven, J.A. Hunter, K.A. 2009. Testing the effects of 794 ocean acidification on algal metabolism: considerations for experimental designs. 795 J. Phycol. 45, 1236-1251.

Irving, A.D., Connell, S.D., Elsdon, T.S., 2004. Effects of kelp canopies on bleaching and 797 photosynthetic activity of encrusting coralline algae. J. Exp. Mar. Biol. Ecol. 310, 1-12. 798 
Johnson, M.D., Carpenter, R.C., 2012. Ocean acidification and warming decrease calcification in the crustose coralline alga Hydrolithon onkodes and increase susceptibility to grazing. J. Exp. Mar. Biol. Ecol. 434-435, 94-101.

Jokiel, P.L., Rodgers, K.S., Kuffner, I.B., Andersson, A.J., Cox, E.F., Mackenzie, F.T., 2008 Ocean acidification and calcifying reef organisms: a mesocosm investigation. Coral Reefs 27, 473-483.

Kamenos, N.A., Moore, P.G., Hall-Spencer, J.M., 2004a. Nursery-area function of maerl grounds for juvenile queen scallops Aequipecten opercularis and other invertebrates. Mar. Ecol. Prog. Ser. 274, 183-189.

Kamenos, N.A., Moore, P.G., Hall-Spencer, J.M., 2004b. Small-scale distribution of juvenile gadoids in shallow inshore waters; what role does maerl play? ICES J. Mar. Sci. 61, 422-429.

Kroeker, K.J., Kordas, R.L., Crim, R.N., Singh, G.G., 2010. Meta-analysis reveals negative yet variable effects of ocean acidification on marine organisms. Ecol. Lett. 13, 1419-1434

Kroeker, K.J., Micheli, F., Gambi, M.C., 2013. Ocean acidification causes ecosystem shifts via altered competitive interactions. Nat. Clim. Chang. 3, 156-159.

Kubler, J.E., Johnston, A.M., Raven, J.A., 1999. The effects of reduced and elevated $\mathrm{CO}_{2}$ and $\mathrm{O}_{2}$ on the seaweed Lomentaria articulata. Plant Cell Environ. 22, 1303-1310.

Kuffner, I.B., Andersson, A.J., Jokiel, P.L., Rodgers, K.S., Mackenzie, F.T., 2008. Decreased abundance of crustose coralline algae due to ocean acidification. Nat. Geosci. 1, 114-117.

Lewis, E., Wallace, D.W.R., 1998. Program Developed for CO2 System Calculations. Carbon Dioxide Information Analysis Center, Oak Ridge National Laboratory, U.S. Department. Littler, M.M., 1972. The crustose Corallinaceae. Annu. Rev. Oceanogr. Mar. Biol. 10, 311-347. Littler, M.M., Littler, D.S., 1998. An undescribed fungal pathogen of reef-forming crustose coralline algae discovered in American Samoa. Coral Reefs 17, 144

Martin, S., Gattuso, J.P., 2009. Response of Mediterranean coralline algae to ocean acidification and elevated temperature. Glob. Change Biol. 15, 2089-2100.

Martin, S., Clavier, J., Guarini, J.-M., Chauvaud, L., Hily, C., Grall, J., Thouzeau, G., Jean, F. Richard, J., 2005. Comparison of Zostera marina and maerl community metabolism. Aquat. Bot. 83 .

Martin, S., Castets, M.D., Clavier, J., 2006. Primary production, respiration and calcification of the temperate free-living coralline alga Lithothamnion corallioides. Aquat. Bot. 85, 121-128.

Martin, S., Clavier, J., Chauvaud, L., Thouzeau, G., 2007. Community metabolism in temperate maerl beds. I. Carbon and carbonate fluxes. Mar. Ecol. Prog. Ser. 335, 19-29.

Martin, S., Rodolfo-Metalpa, R., Ransome, E., Rowley, S., Buia, M.C., Gattuso, J.P. Hall-Spencer, J., 2008. Effects of naturally acidified seawater on seagrass calcareous epibionts. Biol. Lett. 4, 689-692.

Martin, S., Cohu, S., Vignot, C., Zimmerman, G., Gattuso, J.-P., 2013. One-year experiment on the physiological response of the Mediterranean crustose coralline alga, Lithophyllum cabiochae, to elevated $\mathrm{pCO}_{2}$ and temperature. Ecol. Evol.. http://dx.doi.org/10.1002/ ece3.475.

Martone, P.T., Alyono, M. Stites, S., 2010. Bleaching of an intertidal coralline alga: untangling the effects of light, temperature, and desiccation. Mar. Ecol. Prog. Ser. $416,57-67$

Mehrbach, C., Culberso, Ch., Hawley, J.E., Pytkowic, Rm, 1973. Measurement of apparent dissociation-constants of carbonic-acid in seawater at atmospheric-pressure. Limnol. Oceanogr. 18, 897-907.

Middelboe, A.L., Hansen, P.J., 2007. High pH in shallow-water macroalgal habitats. Mar. Ecol. Prog. Ser. 338, 107-117.

Morris, S., Taylor, A.C., 1983. Diurnal and seasonal variation in physicochemical conditions within intertidal rock pools. Estuar. Coast. Shelf Sci. 17, 339-355.

Morse, J.W., Andersson, A.J., Mackenzie, F.T., 2006. Initial responses of carbonate-rich shelf sediments to rising atmospheric $\mathrm{pCO}_{2}$ and "ocean acidification": role of high Mg-calcites. Geochim. Cosmochim. Acta 70, 5814-5830.

Nash, M.C., Opdyke, B.N., Troitzsch, U., Russell, B.D., Adey, W.H., Kato, A., Diaz-Pulido, G., Brent, C., Gardner, M., Prichard, J., Kline, D.I., 2013. Dolomite-rich coralline algae in reefs resist dissolution in acidified conditions. Nat. Clim. Chang. 3, 268-272.

Nelson, W.A., 2009. Calcified macroalgae-critical to coastal ecosystems and vulnerable to change: a review. Mar. Freshwater Res. 60, 787-801.

Orr, J.C., Fabry, V.J., Aumont, O., Bopp, L., Doney, S.C., Feely, R.A., Gnanadesikan, A., Gruber, N., Ishida, A., Joos, F., Key, R.M., Lindsay, K., Maier-Reimer, E., Matear, R., Monfray, P., Mouchet, A., Najjar, R.G., Plattner, G.K., Rodgers, K.B., Sabine, C.L., Sarmiento, J.L. Schlitzer, R., Slater, R.D., Totterdell, I.J., Weirig, M.F., Yamanaka, Y., Yool, A., 2005.
Anthropogenic ocean acidification over the twenty-first century and its impact on 863 calcifying organisms. Nature 437, 681-686. 864

Ouisse, V., Migne, A., Davoult, D., 2011. Community-level carbon flux variability over a 865 tidal cycle in Zostera marina and Z-noltii beds. Mar. Ecol. Prog. Ser. 437, 79-87. 866

Pena, V., Barbara, I., 2010. Seasonal patterns in the maerl community of shallow European 867 Atlantic beds and their use as a baseline for monitoring studies. Eur. J. Phycol. 45, 868 327-342.

Porzio, L, Buia, M.C. Hall-Spencer, J.M., 2011. Effects of ocean acidification on macroalgal 870 communities. J. Exp. Mar. Biol. Ecol. 400, 278-287. 871

Price, N.N., Hamilton, S.L., Tootell, J.S., Smith, J.E., 2011. Species-specific consequences of 872 ocean acidification for the calcareous tropical green algae Halimeda. Mar. Ecol. 873 Prog. Ser. 440, 67-78.

Ragazzola, F., Foster, L.C., Form, A., Anderson, P.S.L., Hansteen, T.H., Fietzke, J., 2012. Ocean 875 acidification weakens the structural integrity of coralline algae. Glob. Change Biol. 18, 876 2804-2812.

Rasband, W.S., 1997-2012. ImageJ. In: U.S.N.I.o (Ed.), Health (imagej.nih.gov/ij/, Bethesda, 878 Maryland, USA). $\quad 879$

Raven, J.A., Hurd, C.L., 2012. Ecophysiology of photosynthesis in macroalgae. Photosynth. 880 Res. 113, 105-125. 881

Raven, J.A., Giordano, M., Beardall, J., Maberly, S.C., 2012. Algal evolution in relation to at- 882 mospheric $\mathrm{CO}_{2}$ : carboxylases, carbon-concentrating mechanisms and carbon oxida- 883 tion cycles. Philos. Trans. R. Soc. B Biol. Sci. 367, 493-507.

Riebesell, U., Fabry, V.J., Hansson, L., Gattuso, J.P., 2010. Guide to best practices for ocean 885 acidification research and data reporting. Publications Office of the European Union, 886 Luxembourg (258 pp.).

Ries, J.B., 2011. Skeletal mineralogy in a high- $\mathrm{CO}_{2}$ world. J. Exp. Mar. Biol. Ecol. 403, 54-64. 888 Ries, J.B., Cohen, A.L., McCorkle, D.C., 2009. Marine calcifiers exhibit mixed responses to 889 $\mathrm{CO}_{2}$-induced ocean acidification. Geology $37,1131-1134$.

Ritchie, RJ. 2008. Universal chlorophyll equations for estimating chlorophylls $a, b$, and $d 891$ and total chlorophylls in natural assemblages of photosynthetic organisms using ac- 892 etone, methanol, or ethanol solvents. Photosynthetica 46, 115-126. 893

Sabine, C.L., Feely, R.A., Gruber, N., Key, R.M., Lee, K., Bullister, J.L., Wanninkhof, R., Wong, 894 C.S., Wallace, D.W. R, Tilbrook, B, Millero, FJ Peng T.H., Kozyr, A Ono, T., Rios, A.F, 895 2004. The oceanic sink for anthropogenic $\mathrm{CO}_{2}$. Science 305, 367-371.

Semesi, I.S., Kangwe, J., Bjork, M., 2009. Alterations in seawater $\mathrm{pH}$ and $\mathrm{CO}_{2}$ affect calcifi- 897 cation and photosynthesis in the tropical coralline alga, Hydrolithon sp (Rhodophyta). 898 Estuar. Coast. Shelf Sci. 84, 337-341.

Smith, A.M., Sutherland, J.E., Kregting, L., Farr, T.J., Winter, D.J., 2012. Phylomineralogy of 900 the Coralline red algae: correlation of skeletal mineralogy with molecular phylogeny. 901 Phytochemistry 81, 97-108.

Solomon, S., Quin, D., Manning, M., Chen, Z., Marquis, M., Averyt, K., Tignor, M., Miler, H., 903 2007. Contribution of Working Group I to the Fourth Assessment Report of the Inter- 904 governmental Panel on Climate Change. Cambridge.

Steneck, R.S., 1986. The ecology of coralline algal crusts-convergent patterns and 906 adaptative strategies. Annu. Rev. Ecol. Syst. 17, 273-303. 907

Teichert, S., Woelkerling, W., Ruggeberg, A., Wisshak, M., Piepenburg, D., Meyerhofer, M., 908 Form, A., Büdenbender, J. Freiwald, A. 2012. Rhodolith beds (Corallinales, 909 Rhodophyta) and their physical and biological environment at 80 degrees $31^{\prime} \mathrm{N}$ in 910 Nordkappbukta (Nordaustlandet, Svalbard Archipelago, Norway). Phycologia 51, 911 371-390.

Tribollet, A., Payri, C., 2001. Bioerosion of the coralline alga Hydrolithon onkodes by 913 microborers in the coral reefs of Moorea. French Polynesia. Oceanol. Acta 24, 914 329-342.

Truchot, J.P., Duhameljouve, A., 1980. Oxygen and carbon-dioxyde in the marine inter- 916 tidal environment-diurnal and tidal changes in rockpools. Respir. Physiol. 39, 917 241-254.

Wolf-Gladrow, D.A., Zeebe, R.E., Klaas, C., Kortzinger, A., Dickson, A.G., 2007. Total alkalin- 919 ity: the explicit conservative expression and its application to biogeochemical pro- 920 cesses. Mar. Chem. 106, 287-300.

Wood, H.L., Spicer, J.I., Widdicombe, S., 2008. Ocean acidification may increase calcifica- 922 tion rates, but at a cost. Proc. R. Soc. B Biol. Sci. 275, 1767-1773.

Zou, D.H., Gao, K.S., Xia, J.R., 2011. Dark respiration in the light and in darkness of three 924 marine macroalgal species grown under ambient and elevated $\mathrm{CO}_{2}$ concentrations. 925 Acta Oceanol. Sin. 30, 106-112. 